\title{
DUAL EDUCATION AS A DIRECTION OF STAFFING FOR AGRARIAN AND INDUSTRIAL COMPLEX
}

\author{
Natalia Anisimova ${ }^{1}$ \\ Petr Maidanevich ${ }^{2}$ \\ Vadim Belik ${ }^{3}$
}

DOI: https://doi.org/10.31410/ITEMA.S.P.2019.23

\begin{abstract}
The article conducted a comprehensive analysis of the state of staffing for agrarian and industrial complex of Russia, including the system of agrarian education as an integral element of the formation of personnel potential of the industry. Problematic issues of qualitative and quantitative imbalance of labor resources in the agricultural sector of the economy have been identified, and possible ways to solve them are reflected. Based on the study of national and foreign experience, the role and importance of dual education for specialists of different professions and levels of qualification are determined, the values of possible socio-economic effect are modeled with recommendations for state and municipal authorities. The results of the research show that the dual education system can not only be an effective way to provide human resources for the agrarian business, but also can adjust the imbalance of jobs, bring into compliance employment programs and actual employment indicators, improve the standard of living of the rural population and the efficiency of agrarian business in general.
\end{abstract}

Keywords: Agrarian Education, Dual Education, Agrarian economy sector, Russian Federation, National projects, Social efficiency, Economic Efficiency.

\section{INTRODUCTION}

C taffing for the agricultural sector of the economy is the most important resource element of the production process in agriculture. In its formation and use it is possible to highlight a number of specific problems of both practical and theoretical-methodological nature. On the one hand, agrarian labour and the goods produced by it are always in demand, this labour doesn't require special education, and access to the market is deprived of many barriers existing in other industries. On the other hand, price parity for agricultural products, high risks of unfavourable weather conditions and the severity of physical work offset the positive factors of agricultural business. In the current conditions, the task of practice is to increase the attractiveness and efficiency of work in agriculture, and the purpose of science is to find and justify optimized directions of staffing.

The term «peopleware» was first introduced in 1987 by Tom De Marco and Timothy Lister (1987), who studied the problem of the human factor in terms of its impact on software development (p. 86). Over the past decades, two subject areas have been identified in human resources research. The first group of scientists considers it as a process of quantitative and qualitative formation of labour resources at different management levels, the second group review it as one of the resources necessary for the functioning of a certain economic system.

1 V. I. Vernadsky Crimean Federal University, Institute of Economics and Management, Sevastopolskaya St. 21/4, Simferopol

2 V. I. Vernadsky Crimean Federal University, Institute of Economics and Management, Sevastopolskaya St. 21/4, Simferopol

3 V. I. Vernadsky Crimean Federal University, Humanitarian and Pedagogical Academy, Sevastopolskaya St. 2, Yalta 
Despite widespread recognition of the second point of view among both domestic (Zorin, Zorina, Safrygin, 2017; Lyula, Divina, 2019), and foreign authors (Strijus, Kravchenya, 2017; Teruyama, Goto, Lechevalier, 2018; Stathakopoulos, Kottikas, Theodorakis, Kottika, 2019), in this context it will be more appropriate to use the term «staff supply». This formulation makes it possible to attribute to this field of research both staff problems of functioning of individual business entities, as well as social and psychological issues of motivational mechanisms and improvement of working conditions of employees (Ecirli, Dobre, Dobrescu, Daniiu, 2014; Salehi-Isfahani, Mostafavi-Dehzooeic, 2018).

At the same time, the process approach to the interpretation of «staff supply» is broader not only from a quantitative point of view, but also from a qualitative point of view, linking its three mandatory components: education, industry and region. Thus, M. A. Kopylova and V. G. Novikov (2008) mean by it «the level of compliance between the quantitative and qualitative labor potential demanded in the labor force market at a particular moment and the activities of organizations providing appropriate programs of staff training and recruitment (system of multilevel general and professional education, retraining and skills improvement of human resources services of enterprises and other institutional structures)» (p. 138).

A similar opinion is expressed by H. H. Iskandarov (2017), describing staff supply as «a system of interaction of methods, forms, resources and tools as well as technologies aimed at reproduction and effective use of work force capital of enterprises, industries, territories and the country, capable of ensuring sustainable and stable development of the economy on the basis of high return of investments» (p. 8).

To sum up staff supply in the frame of the present research denotes a cross-branch process of work force formation and its effective functioning aimed at a quantitative and qualitative balance between the labour market and its participants. At the same time education as a separate system and branch of the economy should participate in the process of staff supply not only at the stage of obtaining basic professional knowledge, but also in increasing the personnel potential of the employee throughout his/her employment. The forms of such interaction can range from skills improvement training courses and internships to additional or second vocational education.

\section{MATERIAL AND METHODS}

The practical application of the acquired skills of employees requires knowledge of the industry in which their enterprise or organization operates. It is noteworthy that most scientific publications of domestic authors, both in specialized periodic editions and dissertations, are devoted to research of staffing for agrarian and industrial complex and agriculture (Anfinogentova, Dudin, Lyasnikov, Protsenko, 2018; Belokopytov, 2015). This indicates both the importance of this industry for the economy of the Russian Federation and the existence of significant problems in the staff supply for the agrarian and industrial complex that have to be settled down.

Staff training for the agricultural sector of the economy in the Russian Federation is provided by 60 higher education institutions of the III-IV level of accreditation ( 26 universities, 33 academies, 1 institute) located in 52 territorial subjects of the Russian Federation and 25 institutions of additional vocational education (institutes and academies of skills improvement training). It should be noted that agrarian universities, along with medical, sports and art educational estab- 
lishments dominate in the structure of industry affiliation of higher educational institutions of Russia with the state ownership (Figure 1). At the same time the largest number of domestic universities (34.0\%) is subordinate to the Ministry of Science and Higher Education of the Russian Federation which is not always appropriate from the point of view of realization of professional competences of training of future specialists.

Figure 1. Structure of higher education institutions of the Russian Federation by industry affiliation and subordination in \%, 2018.

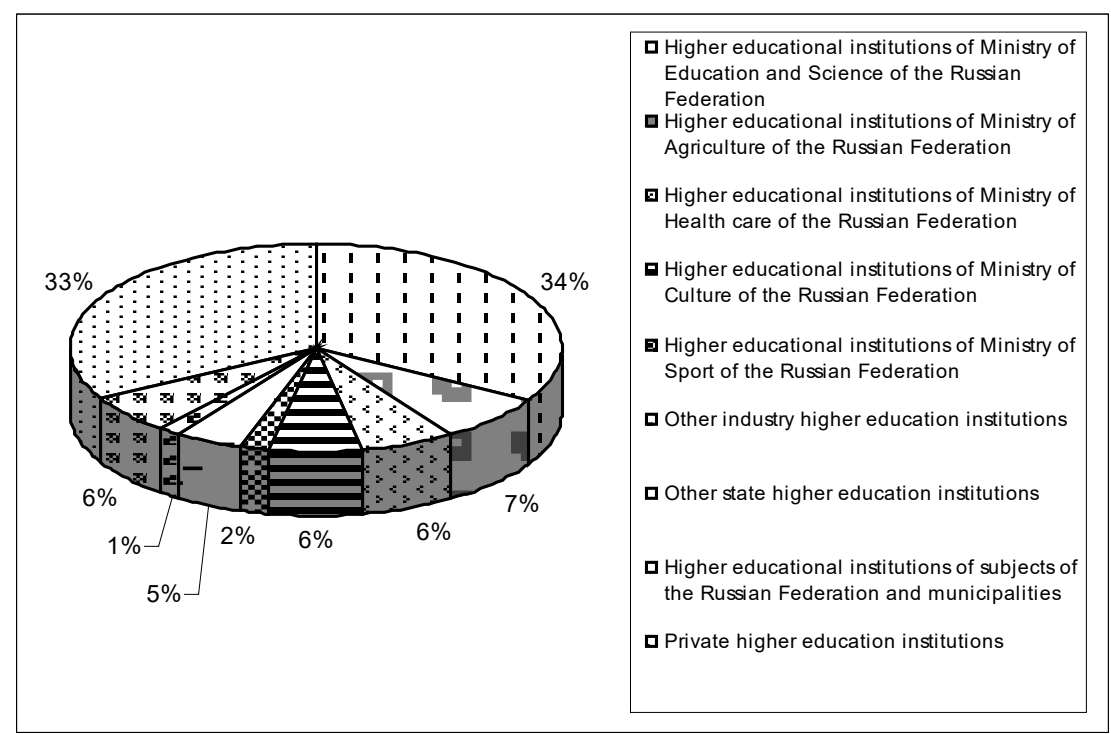

Figure 1. Structure of higher education institutions of the Russian Federation by industry affiliation and subordination in \%, 2018.

Source: Formed by authors according to the Federal Service of State Statistics of the Russian Federation

In the composition of students of higher educational institutions of Russia, students of agrarian areas of training occupy from 3.95 to $6.15 \%$ average, depending on the educational level they choose. According to the statistical data of the Federal Service of State Statistics of the Russian Federation (Table 1) in general, over the last five years from 275546 (2013) to 2,14970 (2018) people have received agricultural qualifications in Russia. Comparison of these indicators demonstrates a decrease in the number of students by 60.6 thousand people or $22.0 \%$ respectively, among them Bachelor's degree - by 2.5 thousand people (1.6\%), by specialization - by 81.5 thousand people (73.7\%). At the same time the number of students of the Master's degree of agrarian Specialization has increased by 23.4 thousand people (246.2\%) during the 2013-2018 periods.

Analyzing the data presented in Table 1, it can be stated that the dynamics observed in the system of Russian agrarian education corresponds to the general trend of significant decrease in number of students studying the Specialization programs and relatively small decrease of students for Bachelor's degree with simultaneous increase in the number of students for Master's degree. It occurs due to the gradual transition of domestic education system to the European standards of the Bologna system which doesn't contain such educational level as Specialization. At the same time the features of some areas of training including agrarian education (veterinary science, landscape design, garden and park economy etc.) do not allow to abandon this educational level completely. 
The study of the agrarian education's role in the general system of higher education institutions of the Russian Federation is also important because about $13.0 \%$ of the total number of students of agrarian higher education institutions of Russia are trained in non-agricultural specialties, but receive professions necessary for the development of rural areas and their infrastructure. They are engineers, economists, financiers, accountants, public civil employees, lawyers, teachers and other necessary specialists in the agricultural sector. In general, staff training with higher vocational education in the agrarian and industrial complex of Russia suggests 122 specialties and 70 directions of Bachelor's degree and Master's degree together with 51 specialties in secondary vocational education.

Thus, it is possible to talk about a rather diverse system of agrarian education both in the Russian Federation as a whole and in its agrarian-oriented regions. However, even with the annual graduation of more than a million agricultural students, Russia's agriculture continues to experience a shortage in the labor force. This is due both to the failure to execute the budget order for certain areas of student training and to the inefficiency of the agricultural educational institutions themselves.

Table 1. Dynamics of changes in the number of students in higher education institutions of the Russian Federation, 2013-2018.

\begin{tabular}{|l|c|c|c|c|c|c|}
\hline Educational level & $\mathbf{2 0 1 3}$ & $\mathbf{2 0 1 4}$ & $\mathbf{2 0 1 5}$ & $\mathbf{2 0 1 6}$ & $\mathbf{2 0 1 7}$ & $\mathbf{2 0 1 8}$ \\
\hline $\begin{array}{l}\text { Bachelor's degree, in } \\
\text { total, people, including: }\end{array}$ & 2994807 & 3516093 & 3530896 & 3263421 & 3032738 & 2902225 \\
\hline - agrarian profile, people & 155319 & 165231 & 194125 & 167506 & 169877 & 152841 \\
\hline - specific weight, \% & 5,19 & 4,70 & 5,50 & 5,13 & 5,60 & 5,27 \\
\hline $\begin{array}{l}\text { Specialization, in total, } \\
\text { people, including: }\end{array}$ & 2453545 & 1465932 & 904868 & 689194 & 703722 & 723278 \\
\hline agrarian profile, people & 110705 & 71066 & 38472 & 27604 & 27807 & 29163 \\
\hline - specific weight, \% & 4,51 & 4,85 & 4,25 & 4,01 & 3,95 & 4,03 \\
\hline $\begin{array}{l}\text { Master's degree, in total, } \\
\text { people, including: }\end{array}$ & 198319 & 226934 & 330715 & 446872 & 509425 & 536169 \\
\hline - agrarian profile, people & 9522 & 9503 & 13211 & 21958 & 29137 & 32966 \\
\hline - specific weight, \% & 4,80 & 4,19 & 3,99 & 4,91 & 5,72 & 6,15 \\
\hline Total, people, including: & 5646671 & 5208959 & 4766479 & 4399487 & 4245885 & 4161672 \\
\hline - agrarian profile, people & 275546 & 245800 & 245808 & 217068 & 226821 & 214970 \\
\hline - specific weight, \% & 4,88 & 4,72 & 5,16 & 4,93 & 5,34 & 5,17 \\
\hline
\end{tabular}

Source: compiled by authors according to the Ministry of Science and Higher Education of the Russian Federation

The Ministry of Education and Science of the Russian Federation refers to the following indicators as signs of inefficiency of higher education institutions: the average score of the unified state examination (not less than 60 score), financing of scientific research (not less than 50 thousand rubles per teacher), number of foreign students among graduates (not less than $0.7 \%$ ), financing from all sources (not less than 1100 thousand rubles per teacher), area of educational buildings per 1 student (not less than 11 sq.m.). Among agrarian universities the Ministry of Education and Science of the Russian Federation identifies $46.0 \%$ of educational institutions as «having signs of inefficiency». Such a high percentage of inefficiency (higher - only in pedagogical universities) is partly due to industry specificity:

- all agrarian universities have lower indicators according to the unified state examination (EGE). This is due not to their inefficiency, but to the low prestige of agricultural professions, as the wage level in agriculture is $50.0 \%$ of the average in the economy 
of the country and rural territories are not socially developed. Therefore, agricultural universities receive graduates of rural schools (more than 60.0\%) who have an average USE score lower than those of urban school graduates;

- agrarian universities have lower indicators on financial criteria due to long ago settled underfinancing (on average 25.0-30.0\% less financial resources are spent per student in agrarian universities from the federal budget than in other universities). The low profitability of agricultural organizations does not allow them to attract funds for scientific research.

In addition, one of the most problematic issues of the modern education system is the imbalance of theoretical and methodological training and practical skills of professional activity. While recently the academic knowledge base was the basis for obtaining a demanded profession and a high-paid position, today for employees of intellectual labor spheres it is rather an exception to the rules. The quantitative growth of higher education institutions has led to the devaluation of the idea of higher education itself, as the availability of a diploma has ceased to guarantee decent employment opportunities. This has also affected the attitude of all participants in the educational process as the students do not understand the link between the knowledge received and the future reward, teachers do not have time to adapt to the rapidly changing conditions of practice.

Scientific research shows that this problem is relevant not only in Russia but also in many foreign countries. One of the directions of its solution is the introduction into the education system the principles of dual education which involve coordinated interaction of educational and industrial environment in training of personnel of a certain profile and level of qualification in accordance with the needs of a specific enterprise. Nowadays dual education as the main training system has been introduced in 60 countries of the world, including Germany, Austria, Serbia, Slovenia, Macedonia, Montenegro, Switzerland, the Netherlands, Denmark, France and some Asian countries.

The dual model of higher vocational education combines classical higher education with vocational education or with practical professional activity in the enterprise. In other words, dual learning takes place at the formal (university) and informal (workplace) levels. The features of dual learning are first of all, not just mastering a set of technical skills and abilities but formation of critical thinking and learning through experience. Secondly, the dual education model regards learning as the result of action and problem-solving in the working environment, that is focused on living projects and situations. Third, dual learning also produces knowledge in a collaborative and collective process that involves discussing different ideas, finding and making optimal decisions. And finally, fourthly, dual education requires the learner not only to acquire new knowledge but also develop such a target competence as the ability to learn.

Despite the fact that Germany is considered the pioneer of the dual education system, it cannot be said that this educational concept is innovative for Russia. As early as 1920 a network of factory apprenticeship schools (FZU) was formed in our country as a unified national system of technical and vocational education. Such schools operated in large enterprises to train skilled workers and were the main type of vocational and technical school in the USSR pre-war time. In later periods, the fundamentals of dual education were included in the principles of the functioning of factory and plant training schools, vocational technical schools and technical institutions of higher education in factories (VTUZ). In industrial enterprises training workshops were established and even in the upper secondary schools, one school day per week was given 
for practical training in production plants. After the collapse of the Soviet Union this system was abolished although in recent years several steps have been taken to resume it, for example, the launch of the project «Training of workers of high-tech industries on the basis of dual education» in 2014. At the same time, today as before agrarian education is involved in this process partially and superficially.

\section{FUTURE RESEARCH DIRECTIONS}

Together with industrial enterprises interested in a high level of practical training of graduates due to the complexity of technological processes, agricultural producers also consider dual education a perspective and promising system. The agricultural sector of the economy works closely with biologically active objects of the plant and animal world, and it's impossible to learn this work within the framework of just theoretical training. Not only agronomists and vets need constant practice in fields and farms, but the economists, accountants, marketers and lawyers engaged in the field of agrarian and industrial complex also require knowledge of features of agricultural production. The possibilities of this highly specialized training are provided by the dual education system.

Today the participation of agrarian and industrial enterprises in professional training of specialists is limited to signing of contracts on targeted training, during which the student is given a workplace to practice and perform graduation qualification work and employment after graduation from the higher education institution. The enterprise can pay the student a scholarship and provide other benefits specified in the contract however, it can demand from him reimbursement of the full cost of training in case of refusal of the graduate to work in the enterprise for at least 3 years after graduation from university. Besides, with targeted training, it is impossible to change a specialty, and the enterprise that sent a student to study and paid the full cost of it does not guarantee him/her a high level of wages and career promotion.

The dual education system is devoid of these shortcomings however it is associated with some others. First, its implementation will require changes in the legal and regulatory documents in the field of higher education, both at the federal and regional levels. In particular, the best management solution of an organizational and administrative nature in this case will be the transfer of agrarian universities in agricultural-oriented regions to the jurisdiction of regional Ministries of Agriculture that will allow to co-finance staff training programs for a specific workplace by commercial enterprises interested in qualified personnel and regional authorities interested in development both economy and rural territories.

Secondly, dual education programs are intended for students with a high level of labour motivation that is not inherent in most of modern applicants. This situation can be corrected by a social and psychological system of professional self-determination, introduced at the national level in school education with using modified techniques of personal management and marketing.

In general, the process of reorganization of the agrarian education system on the principles of dual education can be reflected in the scheme in Figure 2: 


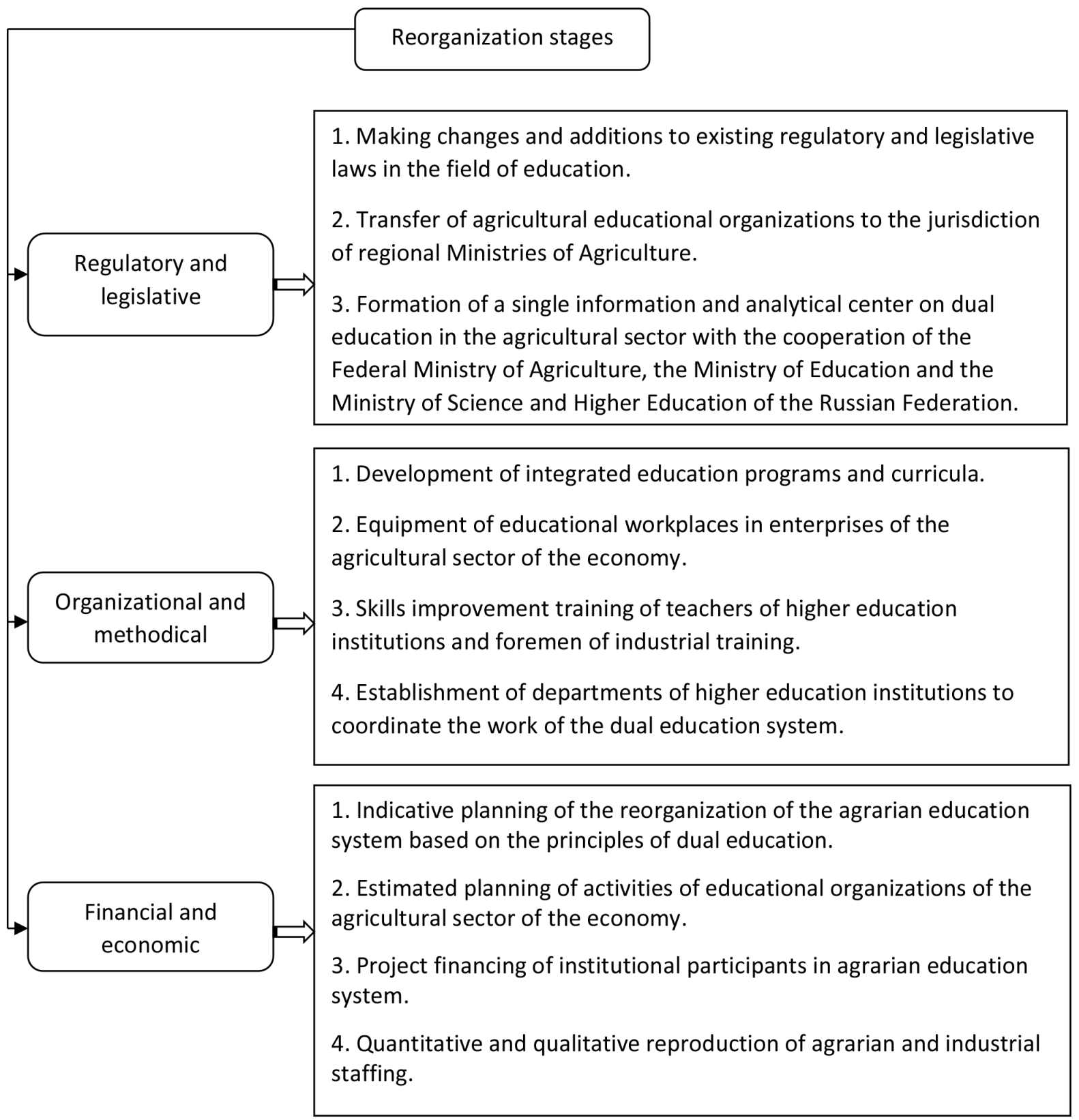

Figure 2. Stages of reorganization of the agrarian education system of the Russian Federation on the principles of dual education

Source: developed by authors

Analysing the proposed stages of reorganization, it should be noted that at present the concept of «dual education» is not regulated in Russia either by the Federal Law «On Education in the Russian Federation» or by other regulatory and legislative laws. At the same time according to the Decree of the President of the Russian Federation «On national goals and strategic tasks of development of the Russian Federation for the period up to 2024», one of the national projects of Russia is «Education», within the framework of which it is possible to distinguish such a separate subprogram as «Dual education».

The reforming of the agrarian education system within the framework of the already existing national project will allow to minimize both organizational and financial risks of the introduction of dual education. Separate subprograms of this project such as «Young Professionals», 
«New Opportunities for Everyone», «Social Elevators for Everyone» contain funds which by their content reflect the stages of reorganization of agrarian education on the principles of dual education. It should be noted that their volume is so sufficient (Table 2) that allows to predict the possible economic results of the proposed changes.

Table 2. Dynamics of financial support volumes for the implementation of the national project «Education» in 2019-2024, million rubles

\begin{tabular}{|l|c|c|c|c|c|c|}
\hline The title of subprogram & $\mathbf{2 0 1 9}$ & $\mathbf{2 0 2 0}$ & $\mathbf{2 0 2 1}$ & $\mathbf{2 0 2 2}$ & $\mathbf{2 0 2 3}$ & $\mathbf{2 0 2 4}$ \\
\hline «Young Professionals» & 28872,23 & 25490,84 & 25465,39 & 25465,39 & 25465,39 & 25485,79 \\
\hline $\begin{array}{l}\text { «Social Elevators for } \\
\text { Everyone» }\end{array}$ & 230,00 & 890,00 & 900,00 & 900,00 & 900,00 & 900,00 \\
\hline $\begin{array}{l}\text { «New Opportunities for } \\
\text { Everyone» }\end{array}$ & 1080,00 & 1080,00 & 1660,00 & 1660,00 & 1660,00 & 2080,00 \\
\hline Total & 30182,23 & 27460,84 & 28025,39 & 28025,39 & 28025,39 & 28465,79 \\
\hline
\end{tabular}

Source: made by the authors according to the Passport of the national project «Education»

The main goal of any national programs and projects is to achieve certain public or socially significant indicators. At the same time the current conditions of the market economy make it necessary to maximize efficient use of spent resources at any management level including the state level.

During various studies (Koudahl, 2010; Remington, 2017) it was found out that the labour productivity of students in dual education programs including the agricultural sector increases from 5.0 to $7.0 \%$ average. At the same time the percentage of employment of graduates of higher education institutions in the specialties chosen by them increases, the qualitative imbalance of labor resources decreases, and in general the situation in the agricultural labour market is now stabilizing. The financial and economic indicators assessment of the functioning of the agricultural education system of the Russian Federation in the dynamics until 2022 is presented in Table 3.

Table 3. Forecast assessment of dual education in the agricultural sector of the Russian Federation

\begin{tabular}{|l|c|c|c|c|c|c|c|}
\hline \multicolumn{1}{|c|}{ Indicators } & $\mathbf{2 0 1 5}$ & $\mathbf{2 0 1 6}$ & $\mathbf{2 0 1 7}$ & $\mathbf{2 0 1 8}$ & $\mathbf{2 0 1 9}$ & $\mathbf{2 0 2 0}$ & $\mathbf{2 0 2 1}$ \\
\hline $\begin{array}{l}\text { Produced gross domestic product } \\
\text { of the industry, billion rubles }\end{array}$ & 3214,8 & 3212,2 & 3270,3 & 3268,6 & - & - & - \\
\hline $\begin{array}{l}\text { Number of employees in the } \\
\text { industry, thousand people }\end{array}$ & 5418,0 & 5374,0 & 5074,5 & 4936,6 & - & - & - \\
\hline $\begin{array}{l}\text { Labor productivity, thousand } \\
\text { rubles/person }\end{array}$ & 593,4 & 597,7 & 644,5 & 662,1 & - & - & - \\
\hline $\begin{array}{l}\text { Number of students in dual } \\
\text { education, thousand people }\end{array}$ & - & - & - & - & 105,2 & 210,8 & 211,0 \\
\hline $\begin{array}{l}\text { Costs of implementing and } \\
\text { operating dual education, million } \\
\text { rubles }\end{array}$ & - & - & - & - & 5260,0 & 6324,0 & 6330,0 \\
\hline $\begin{array}{l}\text { Additional gross domestic product } \\
\text { of the industry, million rubles }\end{array}$ & - & - & - & - & 3482,0 & 8719,9 & 8730,0 \\
\hline $\begin{array}{l}\text { Discount multiplier (Central Bank } \\
\text { of the Russian Federation discount } \\
\text { rate), units }\end{array}$ & - & - & - & - & 1,065 & 1,134 & 1,208 \\
\hline Program Net Present Value (NPV) & - & - & - & - & $(1669,48)$ & 443,31 & 2430,1 \\
\hline Profitability Index (PI) & - & - & - & - & 0,66 & 1,04 & 1,15 \\
\hline
\end{tabular}

Source: made by the authors according to the Passport of the national project «Education» 
As it is shown in Table 3, the forecast indicators of dual education implementation in the agrarian and industry complex of the Russian Federation are based on the actual indicators of its gross domestic product, the number of employees in the industry, productivity of their labor and the number of students of agricultural programs. Despite the existing historical and foreign experience, at the first stage it is not reasonable to introduce dual training in all educational organizations of the agrarian sphere, that's why calculations have been made for $10.0 \%$ of actual students at the moment.

The integrated curricula provide that in the system of dual education the acquiring of the working profession takes place after the first two years of study together with receiving the theoretical knowledge. Respectively, the number of agricultural students that are planned to be transferred to the dual education system is 105.2 thousand in 2019 , and their number will increase to 211.0 thousand people by 2021 . Their productivity was also calculated on the basis of professional skills in the first (50.0\%), second (75.0\%) and third (100.0\%) years of work.

The costs of introduction of the dual education in agrarian universities of Russia will mainly include the form of reward for teachers engaged in the development and testing of new integrated curricula. In the following years the amounts of this type of expenditure will decrease, in proportion to the time of actual use of the new methodological support. With regard to enterprises that are the bases of practice, their material and technical re-equipment for dual education will be minimal as training in real production conditions that is the main goal of the system. It should also be noted that additional payment of specialists of enterprises for working with students can be made by redistributing the wage fund of students in proportion to the skills and abilities acquired by them.

Analysing the data presented in Table 3, it can be stated that despite its public and social importance the introduction of dual education in the agricultural sector of the Russian Federation can bring tangible economic effect. The use in the calculations of generally accepted indicators of the efficiency of investment projects (net present value and profitability index) has showed that since the second year of implementation of the proposed measures, the economy of the industry can receive an additional volume of products forming not only food, but also national security of the state.

\section{CONCLUSION}

In general, the system of dual education in the agrarian and industrial complex of the Russian Federation has reasonable prerequisites not only for the introduction but also for effective interaction with the existing educational structures in order to achieve the uniform purpose of improving the efficiency of the agrarian economy as a whole. Dual training can become not only an effective direction of providing staff support of agrarian and industrial complex but also eliminate the imbalance of jobs, bring in compliance the state, regional, branch employment programs and actual employment indicators, increase the standard of living of rural population and efficiency of agrarian business in general.

As a direction of providing staff supply for the agrarian and industrial complex dual education has all prospects for development not only in the Russian Federation but also in agrarian-oriented regions of other countries, which have not yet implemented its fundamentals in the national educational process. Future specialists studying at specific workplaces are more adapted to the 
conditions of agricultural production and are less dependent on the unfavourable situation in the labour market which makes it possible to speak about the synergetic effect of dual education for the agrarian and industrial complex.

The social or technical effect of the introduction of dual education is evident in the stabilization of the process of staffing of the agrarian and industrial complex; the economic effect is noticeable in the growth of gross domestic product and staff productivity. In the national economy of Russia, the minimum possible effect can constitute up to 2.5 billion rubles annually, and the calculation methodology itself can be used as a basis for determining the efficiency of the reorganization of the agricultural education system on the principles of dual education.

\section{REFERENCES}

DeMarco, T., \& Lister, T. (2013). Peopleware: Productive Projects and Teams. New York: Addison-Wesley Professional.

Zorin, A. S., Zorina, N. A., \& Safrygin, P. A. (2017). Theoretical and methodological approaches to evaluating the impact of staff development on labour efficiency. Upravlenets [The Manager], 1(65), 2-8.

https://elibrary.ru/download/elibrary_29317458_58371102.pdf

Lyula, V. V., \& Divina, T. V. (2019). Staffing as one of the components of the resource saving process. Economics and Business: Theory and Practice, 7, 119-121.

https://doi.org/10.24411/2411-0450-2019-11088

Strijeus, L. V., Kravchenya I. V. (2017). Theoretical and applied aspect of intelligent and staff supply management of the enterprise. Economic Forum, 3, 222-227.

https://elibrary.ru/download/elibrary_29901194_68330209.pdf

Stathakopoulos, V., Kottikas, K. G., Theodorakis, I. G., \& Kottika E. (2019). Market-driving strategy and personnel attributes: Top management versus middle management. Journal of Business Research, 104, 529-540.

https://doi.org/10.1016/j.jbusres.2018.09.020

Teruyama, H., Goto Y., \& Lechevalier S. (2018). Firm-level labor demand for and macroeconomic increases in non-regular workers in Japan. Japan and the World Economy, 48, 90105.

https://doi.org/10.1016/j.japwor.2018.08.006

Ecirli, A., Dobre, E.-M., Dobrescu, E., \& Danetiu, M. I. (2014). Human Resources in European Market in the Past Decade - A Sociological Overview. Procedia - Social and Behavioral Sciences, 150, 320-329.

https://doi.org/10.1016/j.sbspro.2014.09.070

Salehi-Isfahani, D., \& Mostafavi-Dehzooeic M. H. (2018). Cash transfers and labor supply: Evidence from a large-scale program in Iran. Journal of Development Economics, 135, 349367.

https://doi.org/10.1016/j.jdeveco.2018.08.005

Kopylova, M. A., \& Novikov, V. G. (2008). Methodological principles of human resources management. Vestnik Rossijskogo gosudarstvennogo agrarnogo zaochnogo universiteta [Journal of the Russian State Agrarian Correspondence University], 2, 138-139.

Iskandarov, H. H. (2017). Improvement of the motivational mechanism of staff supply of the agricultural sector of the economy (on the materials of the Republic of Tajikistan). Dushanbe:

Tajik National University.

http://tguk.tj/failes/sovet/zashita/iskandarov-hofiz-hak/ 
Anfinogentova, A. A., Dudin, M. N., Lyasnikov, N. V., \& Protsenko, O. D. (2018). Providing the Russian Agro-Industrial Complex With Highly Qualifi ed Personnel in the Context of the Global Transition to a "Green Economy». Ekonomika regiona [Economy of Region], 14(2), 638-650.

https://doi.org/10.17059/2018-2-24

Belokopytov, A. V. (2015). Improving retention of young professionals in the agricultural sector of the regional economy. Ekonomika truda [Russian Journal of Labor Economics], 2(4), 255-266.

https://doi.org/10.18334/et.2.4.1919

Statistical information in research and development and higher education. Official statistics of the Ministry of Science and Higher Education of the Russian Federation.

https://minobrnauki.gov.ru/ru/activity/stat/highed/index.php

Education. Official statistics of the Federal State Statistics Service of the Russian Federation. https://www.gks.ru/folder/13398

Passport of the national project «Education». Approved by the Presidium of the Council under the President of the Russian Federation on Strategic Development and National Projects (Protocol No. 16, 24 $4^{\text {th }}$ December 2018). http://www.consultant.ru/cons/ cgi/online.cgi? $\mathrm{req}=$ doc $\&$ base $=\mathrm{LAW} \& \mathrm{n}=319308 \& \mathrm{fld}=134 \& \mathrm{dst}=1000000001,0 \& \mathrm{r}$ $\mathrm{nd}=0.8046021527064344 \# 012749859705917688$

Koudahl, P. D. (2010). Vocational education and training: dual education and economic crises Procedia - Social and Behavioral Sciences, 9, 1900-1905. https://doi.org/10.1016/j.sbspro.2010.12.421

Remington, T. F. (2017). Public-Private Partnerships in VET: Translating the German Model of Dual Education. The Journal of the New Economic Association, 4(36), 182-188. http:// www.econorus.org/repec/journl/2017-36-182-189r.pdf 